\title{
DIVERSITY OF Vanda tricolor Lindl. (ORCHIDACEAE) FLOWER-VISITING INSECTS IN THE TURGO HILL OF MOUNT MERAPI NATIONAL PARK, YOGYAKARTA, INDONESIA
}

\author{
Angga Putra Kusumastianto ${ }^{1}$, Aninda Retno Utami Wibowo ${ }^{2}$, Anida Metha Anggriasari ${ }^{2}$, \\ Fitra Sukma Meylia ${ }^{1}$, Hendry Susila ${ }^{2}$, Muhammad Bima Atmaja ${ }^{2}$, \\ and R.C. Hidayat Soesilohadi ${ }^{3}$ \\ ${ }^{1}$ Entomology Study Club, Faculty of Biology, UGM \\ ${ }^{2}$ Biology Orchid Study Club, Faculty of Biology, UGM \\ ${ }^{3}$ Lecturer of Faculty of Biology, UGM \\ JI. Teknika Selatan, Sekip Utara, Yogyakarta 55281 \\ Tel: +62-274-580839, 6492350 fax: +62-274-580839 \\ e-mail: angga_putra@mail.ugm.ac.id; kusumastianto@gmail.com
}

\begin{abstract}
Vanda tricolor is an orchid species native to the Mount Merapi National Park, Yogyakarta, Indonesia. The study of interaction flower-visiting insect is important to support in situ conservation program. The purpose of this research wasto study the diversity of Vanda tricolor Lind. flower-visiting insects and their roles in The Turgo Hill of Mount Merapi National Park. Flower-visiting insect was captured in the morning (08.00-10.00 AM), daytime (00.00-02.00 PM) and afternoon (04.00-06.00 PM). Data were taken four times in November 2011 during the flowering season. Insect samples were preserved by dried and wet phase. Sample identification was done in the Entomology Laboratory, Faculty of Biology, Universitas Gadjah Mada. The results indicated that Vanda tricolor flowers were visited by insects from three orders, six families, and eleven species in the morning; four orders, six families, and nine species in the daytime; and two orders, three families, and five species in the afternoon with various role. In this research, we also observed pollination activity potential by Xylocopa latipes (Hymenoptera: Apidae). There were $14 \mathrm{~V}$. tricolor flower-visiting insects from four orders and nine families. There were no significant differences between the insect diversity of the morning and daytime, while in the afternoon there was a decline in the diversity of the insects.
\end{abstract}

Key words: Vanda tricolor, flower-visiting insects, Turgo Hill of Mount Merapi National Park

\section{INTRODUCTION}

Mount Merapi National Park is one of the in situ conservation sites with a highland topography and a humid forest. Susantyo (2011) reported plant biodiversity from this place and Vanda tricolorwas recorded in Mount Merapi National Park as a native orchid species. V. tricolor belongs to Orchidaceae, tribe Vandeae (Carlsward et al., 2006), which has a pleasant fragrant and a red-purple-brown attractive colour (Cullen, 1992). The distributions of V.tricolorin Indonesia were reported in West Java, Central Java (including Yogyakarta), East Java, and Central Sulawesi (Gardiner, 2007). This orchid is well known as native in Java and Bali; one of its natural habitat is Kaliurang, Mount Merapi, Yogyakarta. The cultivation and ecological distribution of $V$. tricolor has been reviewed as a high-valued orchid (Semiarti et al., 2009). However, the rate of self-pollination and cultivation in its native habitat is still low. Pollination in many orchids has been reportedly held by insects (Banziger et al., 2005). We observed the insect visitation if could lead to outcrossing of $V$. tricolor and the role of each visiting-insect. 


\section{MATERIALS AND METHODS Observation}

Observations of the diversity of $V$. tricolor flower-visiting insects were done in three periods: in the morning (08:00 AM to 10:00 AM), daytime (00:00 PM to 02:00 PM), and afternoon (04:00 PM to 06:00 PM), four times during flowering season (November - December). Insects were captured using sweepnet for flying insects and small brush for small insect, and collected for identification purposes. Air temperature and humidity were measured to represent the environmental conditions.

\section{Preservation and Identification}

Collected adult insects were preserved in a dry and wet phase. Dried preservation was done by inserting the dried specimens in an oven at a temperature of $37^{\circ} \mathrm{C}$ for seven days, while the eggs, larvae, nymph or pupa were preserved by wet preservation in $70 \%$ ethanol. Morphological identification was done according to Borror et al., (1992).

\section{RESULT AND DISCUSSION}

Our results show that there were differences in the diversity of $V$. tricolorflower-visiting insects in the morning, daytime and afternoon, as is shown in the Table 1, and the environmental conditions in the Table 2.

Table 1. Diversity of $V$. tricolor Lindl. flower-visiting insect in The Turgo Hill of Mount Merapi National Park, Yogyakarta, Indonesia

\begin{tabular}{|c|c|c|c|c|c|}
\hline \multirow[b]{2}{*}{ No. } & \multirow[b]{2}{*}{ Species Name } & \multirow[b]{2}{*}{ Family } & \multicolumn{3}{|c|}{ Time } \\
\hline & & & $\begin{array}{l}\text { Morning } \\
\text { (08.00AM- } \\
\text { 10.00AM) }\end{array}$ & $\begin{array}{c}\text { Daytime } \\
\text { (00.00PM- } \\
\text { 02.00PM) }\end{array}$ & $\begin{array}{l}\text { Afternoon } \\
\text { (04.00PM- } \\
\text { 06.00PM) }\end{array}$ \\
\hline \multicolumn{6}{|c|}{ Order Diptera } \\
\hline 1. & Dt1 & Calliphoridae & $\sqrt{ }$ & & \\
\hline 2. & $\begin{array}{l}\text { Allograpta obliqua } \\
\text { Say. }\end{array}$ & Syrphidae & $\sqrt{ }$ & & \\
\hline 3. & $\begin{array}{l}\text { Musca domestica } \\
\text { L. }\end{array}$ & Muscidae & $\sqrt{ }$ & $\sqrt{ }$ & $\sqrt{ }$ \\
\hline \multicolumn{6}{|c|}{ Order Coleoptera } \\
\hline 1. & Col1 & Curculionidae & $\sqrt{ }$ & $\sqrt{ }$ & \\
\hline 2. & Col2 & Scarabaeidae & & $\sqrt{ }$ & \\
\hline \multicolumn{6}{|c|}{ Order Hymenoptera } \\
\hline 1. & Myrmicaria sp. & Formicidae & $\sqrt{ }$ & $\sqrt{ }$ & $\sqrt{ }$ \\
\hline 2. & Paratrechina sp. & Formicidae & $\sqrt{ }$ & & \\
\hline 3. & Rotastruma sp. & Formicidae & $\sqrt{ }$ & & \\
\hline 4. & Hy1 & $\begin{array}{l}\text { Formicidae } \\
\text { (Ponerinae) }\end{array}$ & $\sqrt{ }$ & $\sqrt{ }$ & \\
\hline 5. & Lepisiota sp. & Formicidae & $\sqrt{ }$ & $\sqrt{ }$ & $\sqrt{ }$ \\
\hline 6. & $\begin{array}{l}\text { Vespa velutina, } \\
\text { Lepeletier }\end{array}$ & $\begin{array}{l}\text { Vespidae } \\
\text { (Vespinae) }\end{array}$ & $\sqrt{ }$ & & $\sqrt{ }$ \\
\hline 7. & Camponotus sp. & Formicidae & $\sqrt{ }$ & $\sqrt{ }$ & $\sqrt{ }$ \\
\hline & $\begin{array}{l}\text { Xylocopa latipes, } \\
\text { Drury. }\end{array}$ & Apidae & & $\sqrt{ }$ & \\
\hline \multicolumn{6}{|c|}{ Order Lepidoptera } \\
\hline 1. & Amata sp. & $\begin{array}{l}\text { Arctiidae } \\
\text { (Syntominae) }\end{array}$ & & $\sqrt{ }$ & \\
\hline
\end{tabular}


Table 2. Environmental conditions of The Turgo Hill Turgo Hill of Mount Merapi National Park, Yogyakarta, Indonesia

\begin{tabular}{|c|c|c|c|}
\hline & $\begin{array}{l}\text { Morning } \\
\text { (08.00AM- } \\
\text { 10.00AM) }\end{array}$ & $\begin{array}{l}\text { Daytime } \\
\text { (00.00PM- } \\
\text { 02.00PM) }\end{array}$ & $\begin{array}{l}\text { Afternoon } \\
\text { (04.00PM- } \\
\text { 06.00PM) }\end{array}$ \\
\hline Air Temperature $\left({ }^{\circ} \mathrm{C}\right)$ & $27.75 \pm 0.66$ & $27.53 \pm 1.42$ & $24.89 \pm 2.74$ \\
\hline Air Humidity (\%) & $71.33 \pm 6.66$ & $74.29 \pm 6.05$ & $83.3 \pm 11.3$ \\
\hline
\end{tabular}

According to the observations, there were no significant differences in the diversity between the morning and daytime, while in the afternoon there was a decline in the diversity of the visitors. This could be due to diurnal insect activity, which begins to feed in the morning until late afternoon with the highest activity during the day, especially in bright conditions (Khairiah et al., 2012). Insects have different purposes in visiting flowers, such as foraging (Kimball, 2009). Insect-visitors were captured during field observation. Calliphoridae Family (encoded Dipt1) was reportedly a common pollinator, because of their ability to respond to flower colors and nectars. Calliporids can discriminate yellow and blue; yellow color is preferred, except at decaying odour supervenes, brown-purple is preferred. Calliporids were used to pollinate flowers with small size (Jewiss-Gaines et al., 2012). Allograpta obliqua usually visits flower for nectar and considered to be an important pollinator for some plants (Weems, 2011). Musca domestica is considered a potential pollinator for mango plant (Sung et al., 2006). Our observations showed that there were two types of insects from Coleoptera Order: Curculionidae Family (encoded Col1) and Scarabaeidae Family (encoded Col2). Generally, Curculionidae Family lays eggs by making a hole in the stem, leaves, pseudobulbs, and flowers. Furthermore, Curculionidae Family also feeds on the outside of its host. Probably, Col1 acts as insect pests. These insects are diurnal (Prena, 2008). The presence in this study of interest $V$. tricolor found in the morning and daytime. The second insect in Coleoptera Order was Scarabaeidae Family (encoded Col2) that are destructive insects and plant eaters. Some others are dung-feeders or scavengers (Borror et al., 1992). Scarabaeidae that visited $V$. tricolor's flower in this study is probably the scavenger that was interested in the smell of decayed V. tricolor's flower. According to Swezey (1945), Scarabaeidae is not included in the list of insects associated with orchids.

In this study, we found six species of ants (Hymenoptera: Formicidae) that visited the $V$. Tricolor's flower. They are Myrmicaria sp., Paratrechina sp., Rotastruma sp., Lepisiota sp., Camponotus sp., and Hy1 (see Table 3.). Hy1 is the code we provided to the ants of the Ponerinae Subfamily that we could not identify its species' name. These six ants species probably do not have a pollinator role in the $V$. tricolor's flower, because $V$. tricolor's flower does not have a part which is similar with female ants, so the pollination by pseudocopulating male ants is impossible (Peakall, 1989), and the sizes of ants found in this study were much smaller than those of the anther cap of $V$. tricolor's flower, so the possibility of ants can inadvertently open the anther cap during the move is very small (Toro et al., 2012). The role of these six ants species are possibly only as the consumers of nectar or a visitor who were feeding on $V$. tricolor's flower.

Vespa velutina is known as a predator of social wasp and bees. It is one of the most adept hornets at catching honeybees on the wing with the highest predation levels in the morning and afternoon. It is related to the daily rhythm of honeybees flight (Chauzat \& Maryin, 
2009). This may be the reason of $V$. velutina presence as $V$. tricolor flower-visiting insect. $X y l o c o p a ~ l a t i p e s$ was reported as pollinator of Papilionanthe teres (Roxb.). Several orchids from different genera like Phalaenopsis Ridl., Vanda Jones ex R. Br., Eupholia R. Br., and Aerides odorata Lour. Also reported pollinated by Xylocopa (Carr, 1928; Dressler, 1990; Van der Cingel, 2001; Kocyan et al., 2008; Peter, 2009). Flora species that are pollinated by a carpenter bee have common characteristics, like large with strong heavy tissue of flower and sexual part (gynostemium in orchid) must in contact with the dorsal part of the bee (Van der Pijl, 1954). Moreover, a report from Africa and India suggests that the bee from genus Xylocopa has a tendency to pollinate flower with a bright yellow or bright pink color (Peter, 2009; Raju and Rao, 2006).

Amata sp. is member of Arctiidae, a large family of moth. In Kalimantan, there were around 30 species of Amata, distributed from lowland until mountain region (Holloway, 1988). Jakubska et al. (2005) reported Amata sp. as flower-visiting insect in orchid plant Epipactis helleborine (L.) Crantz.; however, the role of the insect is still undetermined.

The flower of $V$. tricolor has a thick, cylindric, $1-2 \mathrm{~m}$ long stem. Leaves $45 \times 5 \mathrm{~cm}$, oblong. Inflorescences erect, 8-15 flowers. Flowers 6-7.5 cm in diameter, fragrant, waxy, short column. Sepals and petals broadly ovate, claw-like base, wavy, yellow spotted with dark pink-purple-dark brown, white base. Labellum trilobed, midlobe broadly oblong, waisted at the middle, basal part boarder than apical, violet-red with purple stripes, short spur (Cullen, 1992; Semiarti et al., 2009). The scent perceivable from $1 \mathrm{~m}$ away when many inflorescences bloom together (Lestari, 2010). Purple stripes on the labellum probably can be one of the attractant for insect-pollinator. Moreover, at the basal part of the column, we found a clear, waxy gel and two yellow spots. Two yellow spots probably had attracts $X$. latipes to came into the spur, while the waxy gels on the basal of the column probably attract many insect to came into the spur. The waxy gels could contain sugar exudate, as reported by Jeffrey et al. (1970). Ants are attracted to orchids due to the presence of sugar containing exudates. The waxy gel could be the only reward offered by $V$. tricolor's flowers. A matching size of insect and flower would increase the possibility of pollination. Fit size flower-insect reported in Epipogium roseum pollination (Zhou et al., 2012). In our research, $X$. latipes has a fit size to $V$. tricolor. The pollen has a great advantage to stick at the thorax (Fig 1.). Presented as two compact mass, yellow, pollen has a sticky viscidium disc. When $X$. latipes tries to exit from the spur, the column has a contact with the dorsal part of $X$. latipes. Then the outer surface of viscidium disc sticks to the thorax. The movement of $X$. latipes coincidentally pulls the anther cap and pollen is removed (Fig 2.)

Diversity fluctuations were influenced by the environmental conditions, including air temperature and humidity. Based on the observations, temperature and humidity affected the diversity of insects-visitors. The diversities of insect visitors in the morning and daytime were quite similar when the temperature and humidity levels were equal, then decreased in the afternoon with a decreasing temperature and increasing humidity. Insect is a poikilothermic organism whose body temperature is affected by the environmental temperature (Borror et al., 1992). 


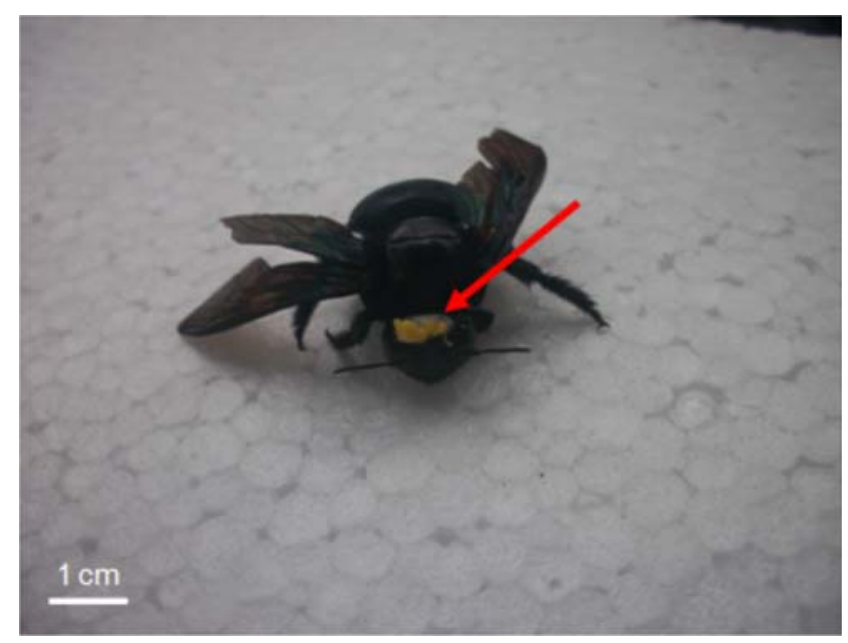

Figure 1. Xylocopa latipes, pollinator potential of V. tricolor with gynostemium on the thorax

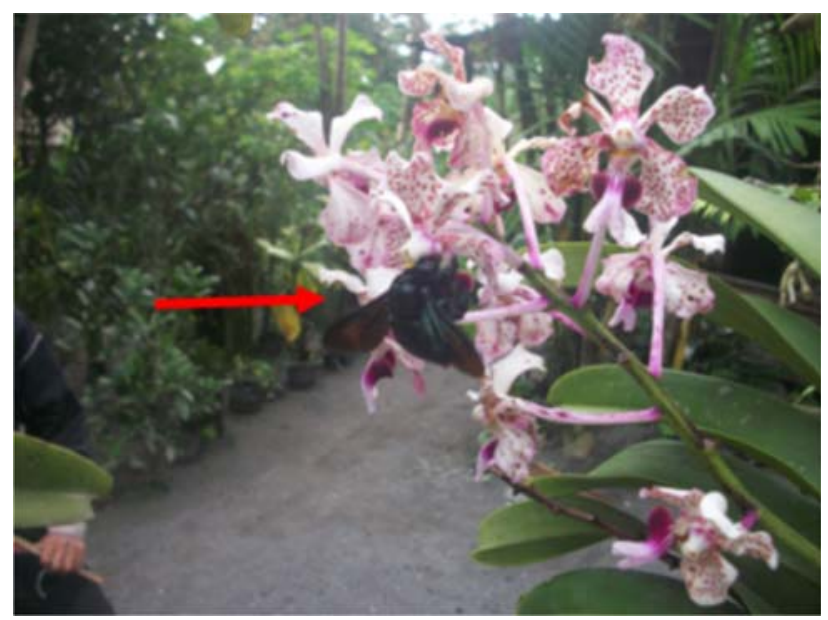

Figure 2. X. latipes entering the flower of $V$. tricolor

\section{CONCLUSION}

There were 14 species of $V$. tricolor flower-visiting insects from four orders and nine families. There were no significant differences in the diversity between the morning and daytime, while in the afternoon there was a decline in the diversity of the visit. While the most potential pollinator was showed by Xylocopa latipes, further work is needed to test the percentage of pollen removal to resolve the mechanism of $X$. latipes attracted to $V$. tricolor.

\section{REFERENCES}

Banziger, H., H. Sun, and Y. Luo.2005. Pollination of a slippery lady slipper orchid in southwest China: Cypripedium guttatum (Orchidaceae). Botanical Journal of the Linnean Society. 148: 251-264.

Borror, D. J., C.A. Triplehorn, N.F. Johnson. 1992. Introduce to Entomology. Diterjemahkan oleh S. Partosodjono. Edisi ke-6. UGM Press.

Carlsward, B.S., W.M. Whitten, N. H. Williams, and B. Bytebier. 2006. Molecular Phylogenetics of Vandeae (orchidaceae) and The Evolution of Leaflessness. American Journal of Botany. 93(5): 770-786. 
Carr, C.E. 1928. Orchid Pollination Notes. J. of The Malay. Branch of The Royal Asiatic Soc. 6:49-72.

Chauzat, M.P., \& S. Martin. 2009. A foreigner in France: The Asian hornet. Biologist 56 (2): 86-91.

Cullen, J. 1992. The Orchid Book. Cambridge University Press, Britain. p. 381.

Dressler, R.L. 1990. The Orchid-Natural History and Classification. London. Harvard University Press.

Gardiner, L.M. 2007. Vanda tricolor Lindl. Conservation In Java, Indonesia: Genetic and Geographic Structure and History. Lankesteriana 7(1-2): 272-280.

Holloway, J.D. 1988. The Months of Borneo, Part 6: Family Arcitiidae, Subfamilies Syntomine, Euchromiinae, Arciinae; Noctuidae misplaced in Arcitiidae. http:// www.mothsofborneo.com/part-6/checklist.php. Accessed: $15^{\text {th }}$ August 2013.

Jakubska, A., M. Kadej, D. Przado, and M. Steininger. 2005. Pollination Ecology of Epipactis helleborine (L.) Crantz (Orchidaceae, Neottieae) in the South Western Poland. Acta Botanica Silesiaca 2:131-144.

Jeffrey, D.C., J. Arditti, and H. Koopowitz. 1970. Sugar Content in Floral and Extrafloral

Exudates of Orchids: Pollination, Myrmecology and Chemotaxonomy Implication. New Phytologist 69 (1): 187-195.

Jewiss-Gaines, A., S.A. Marshall, T. L. Whitworth. 2012. Cluster Flies (Calliphoridae:

Polleniinae: Pollenia) of North America. Canadian J. of Arthr. Ident. 19.

Khairiah, N, Dahelmi, and Syamsuardi. Jenis-jenis Serangga Pengunjung Bunga PAcar Air

(Impatiens balsamina Linn.: Balsaminaceae). 2012. J. Bio. UA. 1 (1): 9-14

Kimball, S. 2009. The Insects That Visit Penstemon Flowers. Bull. of The Am. Penstemon Soc. 68 : $20-45$

Koycan, A., E.F. de Vogel, E. Conti, and B. Gravendeel. 2008. Molecular Phylogeny of Aerides

(Orchidaceae) Based on One Nuclear and Two Plastid Markers: a Step Forward in Understanding The Evolution of Aeridinae. Molec. Phylogenetics and Evo. 48: 422443.

Lestari, E.S. 2010. Karakterisasi Morfologis dan Molekular Anggrek Alam Vanda tricolor Lindl. var suavis Lindl. Asal Merapi dan Bali. Skripsi Fakultas Biologi UGM, Yogyakarta. pp: $40-50$.

Peakall, R. 1989. The unique pollination of Leporella fimbriata (Orchidaceae) - pollinatuon by pseudocopulating male ants (Myrmecia urens, Formicidae). Plant Syst. and Evol. 167: 137-148.

Peter C.I. 2009. Pollination, Floral Deception and Evolutionary Processes in Eulophia (Orchidaceae) and its Allies. PhD thesis, University of KwaZulu-Natal, South Africa.

Prena, J. 2008. A synopsis of the orchid weevil genus Orchidophilus Buchanan (Curculionidae, Baridinae), with taxonomic rectifications and description of one new species. Zootaxa 1783: 18-30.

Raju, A. J. S. \& S. P. Rao. 2006. Nesting Habits, Floral Resources and Foraging Ecology of Large Carpenter Bee (Xylocopa latipes \& Xylocopa pubescens) in India. Curr. Sci. 90(9): 1210-1217. 
Semiarti, E., A. Purwantoro, R. Dwiyani, E. S. Lestari, and T. Swandari. 2009. Perbandingan karakter morfologi dan molekuler Vanda tricolor Lindl. var suavis forma Merapi dan Vanda tricolor Lindl. var suavis forma Bali. Proceeding of Seminar Nasional Biologi XX dan Kongres PBI XIV UIN Maliki Malang 2009. pp: 277-281.

Sung, I, M. Lin, C. Chang, A. Cheng, and W. Chen. 2009. Pollinators and Their Behaviors on Mango Flowers in Southern Taiwan. Formosan Entomol. 26: 161-170.

Susantyo, J. M. 2011. Inventarisasi Keanekaragaman Jenis Tumbuhan di Kawasan Taman Nasional Gunung Merapi. Skripsi. Institu Pertanian Bogor.

Swezey, O. H. 1945. Insects associated with orchids. Proc. Haw. Ent. Soc. 12 (2): 343-403. Toro, I. D., R.R. Ribbons, and S.L. Pelini. 2012. The little things that run the world revisited: a review of ant-mediated ecosystem services and disservices (Hymenoptera: Formicidae). Myrmecological News 17: 133-146.

Van der Cingel, N. A. 2001. An Atlas of Orchid Pollination-America, Africa, Asia and Australia. Rotterdam. A.A. Balkema.

Van der Pijl, L. 1954. Xylocopa and Flower in Tropics. The Bees as Polinators. List of Flower Visited. Knonkl.Nederl.Akademie van Wetenschlappen (Amsterdam) 57:413-423.

Weems, H.V. 2011. A Hover Fly, Allograpta oblique (Say) (Insecta: Diptera: Syrphidae). University of Florida. IFAS Extension. pp. 1-4.

Zhou, X., H. Lin, X.-L. Fan, and J.-Y. Gao. 2012. Autonomous self-pollination and insect visitation in a saprophytic orchid, Epipogium roseum (D.Don) Lindl. Aust. J. of Botany. 60:154-159. 